\title{
A new cell morphotype among methane oxidizers: a spiral-shaped obligately microaerophilic methanotroph from northern low-oxygen environments
}

\author{
Olga V Danilova ${ }^{1}$, Natalia E Suzina ${ }^{2}$, Jodie Van De Kamp ${ }^{3}$, Mette M Svenning ${ }^{4}$, \\ Levente Bodrossy ${ }^{3}$ and Svetlana N Dedysh ${ }^{1}$ \\ ${ }^{1}$ Winogradsky Institute of Microbiology, Research Center of Biotechnology of the Russian Academy of \\ Sciences, Moscow, Russia; ${ }^{2}$ G.K. Skryabin Institute of Biochemistry and Physiology of Microorganisms, \\ Russian Academy of Sciences, Pushchino, Moscow Region, Russia; ${ }^{3}$ CSIRO Oceans and Atmosphere, Hobart, \\ Tasmania, Australia and ${ }^{4}$ UiT The Arctic University of Norway, Department of Arctic and Marine Biology, \\ Tromsø, Norway
}

\begin{abstract}
Although representatives with spiral-shaped cells are described for many functional groups of bacteria, this cell morphotype has never been observed among methanotrophs. Here, we show that spiral-shaped methanotrophic bacteria do exist in nature but elude isolation by conventional approaches due to the preference for growth under micro-oxic conditions. The helical cell shape may enable rapid motility of these bacteria in water-saturated, heterogeneous environments with high microbial biofilm content, therefore offering an advantage of fast cell positioning under desired high methane/low oxygen conditions. The pmoA genes encoding a subunit of particulate methane monooxygenase from these methanotrophs form a new genus-level lineage within the family Methylococcaceae, type lb methanotrophs. Application of a pmoA-based microarray detected these bacteria in a variety of high-latitude freshwater environments including wetlands and lake sediments. As revealed by the environmental pmoA distribution analysis, type $\mathrm{lb}$ methanotrophs tend to live very near the methane source, where oxygen is scarce. The former perception of type Ib methanotrophs as being typical for thermal habitats appears to be incorrect because only a minor proportion of pmoA sequences from these bacteria originated from environments with elevated temperatures.

The ISME Journal (2016) 10, 2734-2743; doi:10.1038/ismej.2016.48; published online 8 April 2016
\end{abstract}

\section{Introduction}

Aerobic methanotrophs are a unique subset of methylotrophic bacteria that have the ability to grow on methane $\left(\mathrm{CH}_{4}\right)$ as a sole carbon and energy source (Trotsenko and Murrell, 2008; Chistoserdova and Lidstrom, 2013). A defining characteristic of these microorganisms is the use of methane monooxygenase (MMO) enzymes to catalyze the oxidation of methane to methanol. Two forms of MMO have been found, that is, the membrane-associated or particulate MMO and the soluble MMO (Trotsenko and Murrell, 2008; Semrau et al., 2010). Soluble MMO occurs in some species only, while nearly all known methanotrophs possess particulate MMO.

Correspondence: SN Dedysh, Wetland Microbiology, Winogradsky Institute of Microbiology, Research Center of Biotechnology of the Russian Academy of Sciences, Leninsky Ave. 33/2, Moscow 119071, Russia.

E-mail: dedysh@mail.ru

Received 5 November 2015; revised 5 February 2016; accepted 25 February 2016; published online 8 April 2016
Therefore, the pmoA gene encoding $\beta$-subunit of particulate MMO is widely used as a functional gene marker for methanotrophs (McDonald et al., 2008; Dumont, 2014). The vast majority of pmoA gene sequences that are currently deposited in the GenBank database were obtained in cultivationindependent studies; only $3 \%$ of these sequences were retrieved from cultured methanotrophic bacteria (Knief, 2015). Many currently recognized pmoA lineages, therefore, are not represented by characterized organisms, and this limits interpretation of results obtained in $p m o A$-based studies.

The currently known diversity of aerobic methanotrophs includes representatives of the phyla Proteobacteria and Verrucomicrobia (Bowman, 2006; Op den Camp et al., 2009). The latter were only recently discovered and appear to be restricted to acidic geothermal environments (Sharp et al., 2014). By contrast, methanotrophic proteobacteria occur in a wide range of habitats where both methane and oxygen are available (Nazaries et al., 2013) and affiliate with the classes Gammaproteobacteria 
(type I methanotrophs) and Alphaproteobacteria (type II methanotrophs). Type I methanotrophs utilize the ribulose monophosphate pathway for formaldehyde assimilation, while type II methanotrophs employ the serine pathway. One additional type of gammaproteobacterial methanotrophs, type X, was originally proposed for Methylococcus capsulatus, which, in addition to ribulose monophosphate pathway, possesses ribulose-1,5-bisphosphate carboxylase/oxygenase (RubisCO), a key enzyme in the Calvin-Benson cycle (Whittenbury and Dalton, 1981; Whittenbury, 1981). Several Methylococcus-related methanotrophs have been described including the genera Methylocaldum (Bodrossy et al., 1997; Takeuchi et al., 2014), Methyloparacoccus (Hoefman et al., 2014) and Methylogaea (Geymonat et al., 2010). Members of these genera form a monophyletic cluster in $p m o A$ gene-based trees and are lately addressed as type $\mathrm{Ib}$ methanotrophs. Respectively, other representatives of the family Methylococcaceae are defined as type Ia methanotrophs. This separation into type Ia and Ib methanotrophs has no taxonomic meaning and is used mostly in molecular diversity studies.

Currently described methanotrophic bacteria display a wide variety of cell shapes, including straight and curved rods, cocci and ovoids, sarcina-like aggregates and filaments, vibrioids and pear-like cells (Bowman, 2006; Stoecker et al., 2006). A morphotype represented by spiral-shaped cells, however, has never been reported for methanotrophs, although it is quite common among heterotrophs, phototrophs, sulfate reducers and methanogens. Here, we present the first example of a spiral-shaped aerobic methanotroph, which has eluded isolation thus far, presumably because of its preference for growth under micro-oxic conditions.
This microaerophilic methanotroph represents a pmoA lineage, which has been detected in several culture-independent studies but for which no culture had previously been ascribed.

\section{Materials and methods}

\section{Sampling sites}

The peat sample used as the isolation source of bacteria described in this study was obtained from the acidic ( $\mathrm{pH}$ 4.7) Sphagnum-dominated peat bog Shumnovo (N 56 $42^{\prime}$, E $36^{\circ} 52^{\prime}$, Tver region, Russia) in June 2012. The sampling was done at the oxic-anoxic interface of the bog profile, at a depth of $15 \mathrm{~cm}$. The samples collected from various wetlands, soils and freshwater sediments in Northern Russia and Norway were used to examine the environmental distribution of spiral-shaped methanotrophs (Table 1).

\section{Cultivation experiments}

Five grams of peat material was placed into a 500-ml serum bottle containing $100 \mathrm{ml}$ mineral medium MG containing ( $\mathrm{mg} \mathrm{l}^{-1}$ ): $\mathrm{KH}_{2} \mathrm{PO}_{4}-30, \mathrm{KNO}_{3}-30, \mathrm{MgSO}_{4}-$ $30, \mathrm{NaCl}-30, \mathrm{CaCl}_{2} \times 2 \mathrm{H}_{2} \mathrm{O}-20$; trace element stock solution (Bowman, 2006), 0.1\% (v/v); pH 6.0. The bottle was closed by silicone rubber septum, $\mathrm{CH}_{4}$ was added to the headspace up to $20 \%(\mathrm{v} / \mathrm{v})$ and the bottle was incubated in static conditions at $24^{\circ} \mathrm{C}$ for 1 month. Multiple dilution series were prepared using the same mineral medium MG with addition of $0.15 \%(\mathrm{v} / \mathrm{v})$ vitamin solution containing $\left(\mathrm{mgl}^{-1}\right)$ : biotin-2, folic acid -2 , pyridoxine-HCl-10, riboflavine -5 , thiamine$\mathrm{HCl} \times 2 \mathrm{H} 2 \mathrm{O}-5$, nicotinamide -5 , D-Ca-pantothenate5 , vitamin $\mathrm{B}_{12}-0.1$, p-aminobenzoic acid-5 (Wolin et al., 1963).

Table 1 Location of the sampling sites and type of samples examined for the presence of spiral-shaped methanotrophs by means of pmoA-based microarray in this study (Figure 2b and Supplementary Figure S4)

\begin{tabular}{|c|c|c|c|c|c|c|}
\hline No & Ecosystem & $\begin{array}{l}\text { Sample } \\
\text { type }\end{array}$ & Country, location & $T\left({ }^{\circ} C\right)^{\mathrm{a}}$ & pH & $\begin{array}{l}\text { Sampling } \\
\text { time }\end{array}$ \\
\hline 1 & River Kuja & sediment & $\begin{array}{l}\text { Russia, Nenets autonomous district, N } 67^{\circ} 36^{\prime} 34^{\prime \prime} \\
\text { E } 53^{\circ} 35^{\prime} 19^{\prime \prime}\end{array}$ & +8 & 6.0 & 08.2014 \\
\hline 2 & Unnamed lake & sediment & $\begin{array}{l}\text { Russia, Nenets autonomous district, N } 67^{\circ} 36^{\prime} 45^{\prime \prime} \\
\text { E } 53^{\circ} 37^{\prime} 20^{\prime \prime}\end{array}$ & +10 & 5.7 & 08.2014 \\
\hline 3 & River Kuja & sediment & $\begin{array}{l}\text { Russia, Nenets autonomous district, N } 67^{\circ} 36^{\prime} 57^{\prime \prime} \\
\text { E } 53^{\circ} 36^{\prime} 15^{\prime \prime}\end{array}$ & +8 & 7.1 & 08.2014 \\
\hline 4 & Sphagnum peat bog & peat & 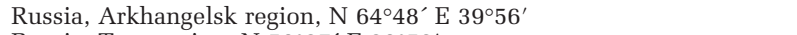 & +12 & 3.9 & 07.2012 \\
\hline 5 & Sphagnum peat bog & peat & Russia, Tver region, N 56 $37^{\prime}$ E $36^{\circ} 52^{\prime}$ & +13 & 3.9 & 06.2012 \\
\hline 6 & Sphagnum peat bog & peat & 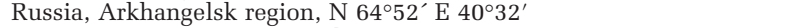 & +10 & 3.9 & 07.2012 \\
\hline 7 & Sphagnum peat bog & peat & $\begin{array}{l}\text { Russia, Nenets autonomous district, N } 67^{\circ} 36^{\prime} 54^{\prime \prime} \\
\text { E } 53^{\circ} 42^{\prime} 07^{\prime \prime}\end{array}$ & +4 & 3.9 & 08.2014 \\
\hline 8 & Sphagnum peat bog & peat & Russia, Yamalo-Nenets autonomous district, N 65 $35^{\circ} 01^{\prime \prime} \mathrm{E} 73^{\circ} 03^{\prime} 05^{\prime \prime}$ & +4 & 4.0 & 07.2014 \\
\hline 9 & Lichen tundra & soil & $\begin{array}{l}\text { Russia, Nenets autonomous district, N } 67^{\circ} 37^{\prime} 09^{\prime \prime} \\
\text { E } 53^{\circ} 49^{\prime} 23^{\prime \prime}\end{array}$ & +10 & 4.2 & 08.2014 \\
\hline 10 & Forested tundra & soil & 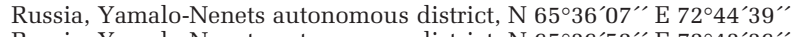 & +12 & 4.2 & 07.2014 \\
\hline 11 & Lichen tundra & soil & 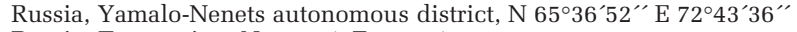 & +12 & 4.0 & 07.2014 \\
\hline 12 & Sphagnum peat bog & peat & Russia, Tver region, N 56² $42^{\prime}$, E $36^{\circ} 52^{\prime}$ & +14 & 4.7 & 06.2012 \\
\hline 13 & Sphagnum thermokarst & $\begin{array}{l}\text { pond } \\
\text { sediment }\end{array}$ & $\begin{array}{l}\text { Norway, Neiden } \\
\text { N } 69^{\circ} 41^{\prime} 089^{\prime \prime} \\
\text { E } 29^{\circ} 11^{\prime} 930^{\prime \prime}\end{array}$ & +12 & 4.2 & 10.2011 \\
\hline 14 & Collapsed Sphagnum palsa & peat & $\begin{array}{l}\text { Norway, Neiden } \\
\text { N } 69^{\circ} 41^{\prime} 116^{\prime \prime} \\
\text { E } 29^{\circ} 11^{\prime} 752^{\prime \prime}\end{array}$ & +10 & 4.6 & 07.2010 \\
\hline
\end{tabular}

aTemperature at time of sampling. 
Electron microscopy

For preparation of ultrathin sections, cells of the exponentially growing cultures were collected by centrifugation and pre-fixed with $1.5 \%(\mathrm{w} / \mathrm{v})$ glutaraldehyde in $0.05 \mathrm{~m}$ cacodylate buffer $(\mathrm{pH} 6.5)$ for $1 \mathrm{~h}$ at $4{ }^{\circ} \mathrm{C}$ and then fixed with $1 \%(\mathrm{w} / \mathrm{v}) \mathrm{OsO}_{4}$ in the same buffer for $4 \mathrm{~h}$ at $20^{\circ} \mathrm{C}$. After dehydration in an ethanol series, the samples were embedded into Epon 812 epoxy resin. Thin sections were cut on an LKB-4800 microtome (LKB-Produkter AB, Stockholm, Sweden), stained with $3 \%(\mathrm{w} / \mathrm{v})$ uranyl acetate in $70 \%(\mathrm{v} / \mathrm{v})$ ethanol, and then were stained with lead citrate (Reynolds, 1963) at $20^{\circ} \mathrm{C}$ for 4 $5 \mathrm{~min}$. For negative staining, cells were dried onto grids and treated with $0.3 \%$ aqueous solution of uranyl acetate $(\mathrm{pH} 4.0)$. The specimen samples were examined with a JEM-1200EX (JEOL, Tokyo, Japan) transmission electron microscope at an accelerating voltage of $80 \mathrm{kV}$.

\section{PCR amplification, cloning and sequencing}

PCR-mediated amplification of the 16S rRNA gene fragments was performed using primers of and 1492r and reaction conditions described by Weisburg et al. (1991). Partial fragments of the pmoA genes were amplified using the primers A189f and A682r and the reaction conditions described by Holmes et al. (1995). PCR-based retrieval of the $c b b L$ gene coding for the large subunit of form I RubisCO was performed using the primers and the reaction conditions described by Alfreider et al. (2003). PCR mixtures $(100 \mu \mathrm{l})$ contained $1 \mu \mathrm{l}$ of template DNA, $50 \mu$ of $2 \times$ MasterMix (Promega, Madison, WI, USA) and $0.3 \mu \mathrm{M}$ of each primer (Syntol, Moscow, Russia). PCR amplifications were performed in a DNA thermal cycler (model 9700; PE Applied Biosystems, Foster City, CA, USA). The resulting PCR products were cloned using a pGEM-T Easy Vector System II (Promega) according to the manufacturer's instructions. Clones were screened for the correct insert with T7 and SP6 primers. Plasmid DNA was purified using Wizard Plus Minipreps DNA Purification System (Promega) and the cloned inserts were sequenced using an ABI 377A sequencer (PerkinElmer Applied Biosystems).

\section{Whole-cell hybridization}

Cells were fixed for $1 \mathrm{~h}$ with $4 \%$ (wt/vol) freshly prepared paraformaldehyde solution. A combination of two Cy3-labeled oligonucleotide probes M84 and M705 (Eller et al., 2001) was applied for specific detection of type I methanotrophs in enrichment cultures of methanotrophic bacteria. The major $16 \mathrm{~S}$ rRNA gene sequence type amplified from DNA of a culture enriched with spiral-shaped cells (see above) was used to design two novel 16S rRNA-targeted oligonucleotide probes for the specific detection/ visualization of the respective bacterium. These probes, Spr206 (5'-CCGGCGGGAGGTCTTGCG-3') and Spr845 (5'-GCTGCGCCACTGACAGCT-3') were formulated using the 'probe design' tool of ARB program package (Ludwig et al., 2004). The specificity of the two newly designed probes was further confirmed using the probe match tool of the Ribosomal Database Project (Release 11). Hybridizations and examination of the specimen samples were performed as described elsewhere (Dedysh et al., 2001).

\section{Chemotaxis experiments}

To determine $\mathrm{CH}_{4}$ - and $\mathrm{O}_{2}$-tactic responses of target spiral-shaped bacteria we used a modified version of the assay described by Tout et al. (2015). Briefly, sterile 5-ml syringes without plungers were filled with $2 \mathrm{ml}$ of semisolid $(0.3 \%$ agar, w/v) medium MG and were inserted into $100-\mathrm{ml}$ vials containing $5 \mathrm{ml}$ of examined cell suspensions, so that cells were given a possibility to migrate into the syringe. The opposite ends of syringe tubes were then closed by rubber septa and flushed with a methane:air mixture (50:50). Both the culture of spiral-shaped bacteria and the culture of the non-spiral motile methanotroph, Methylomonas methanica S1, were used in these tests. The culture of Methylomonas methanica S1 was kindly provided by Dr VN Khmelenina. Control incubations were prepared in the same way but without $\mathrm{CH}_{4}$ in the headspace. Both the experimental and control tests were made in three replicates. The incubations were carried out in static conditions at $20^{\circ} \mathrm{C}$. Each $4 \mathrm{~h}$, three syringes, with and without methane, were withdrawn and checked for the presence of target cells in the near-surface (depth $2 \mathrm{~mm}$ ) agar layer. For this, $20 \mu \mathrm{l}$ of semisolid agar was sampled from this layer and evenly distributed on Teflon-laminated slides with eight wells for independent positioning of the samples. Cell counting was performed in 20 fields of view using a Zeiss Axioplan 2 microscope (Zeiss, Jena, Germany).

\section{pmoA microarray analysis}

Genomic DNA extracted from the samples listed in Table 1 was used as a template in a touchdown PCR, from 62 to $52{ }^{\circ} \mathrm{C}$ in 11 cycles and 25 cycles at $52^{\circ} \mathrm{C}$, with the $p m o A$ primer set A189/T7-A682. This PCR product was further used for a nested pmoA touchdown PCR, with the pmoA primer set A189/ T7-mb661, from 62 to $52{ }^{\circ} \mathrm{C}$ in 11 cycles and 15 cycles at $52{ }^{\circ} \mathrm{C}$. The reverse primers used in these reactions contained a T7 tag that enabled subsequent in vitro transcription. The resulting PCR product was used to generate fragmented, Cy3-labeled RNA target via in vitro transcription and the target was used for hybridization on $p m o A$ microarray slides as described earlier (Stralis-Pavese et al., 2011). Hybridized slides were scanned at $10 \mu \mathrm{m}$ resolution with a GenePix 4000 laser scanner (Axon, Foster City, CA, USA) at a wavelength of $532 \mathrm{~nm}$. Fluorescent images were analyzed with the GenePix software (Axon). Microsoft Excel was used for statistical analysis and presentation of results. Hybridization between a probe and a target was considered in analyses if the signal was at 

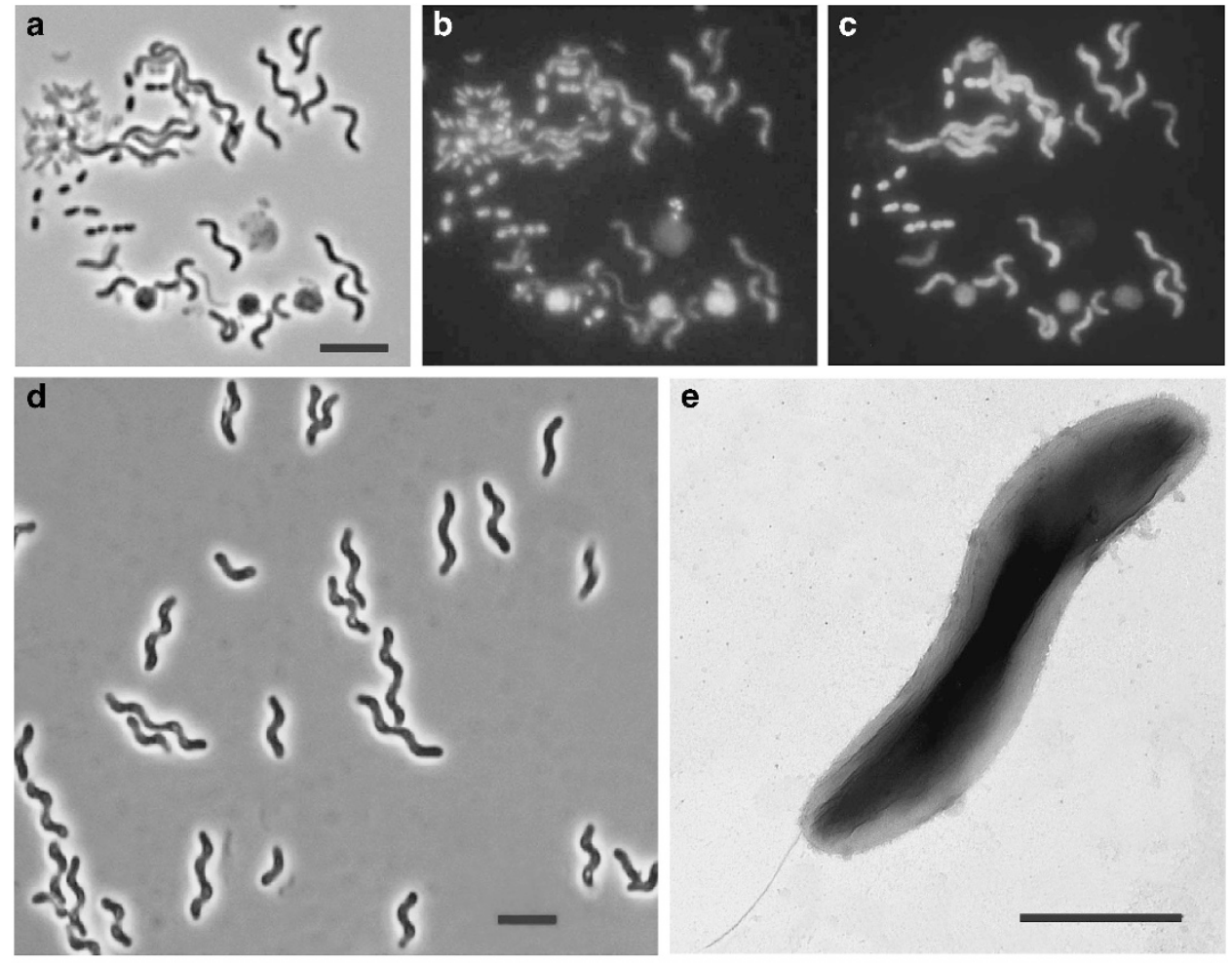

e
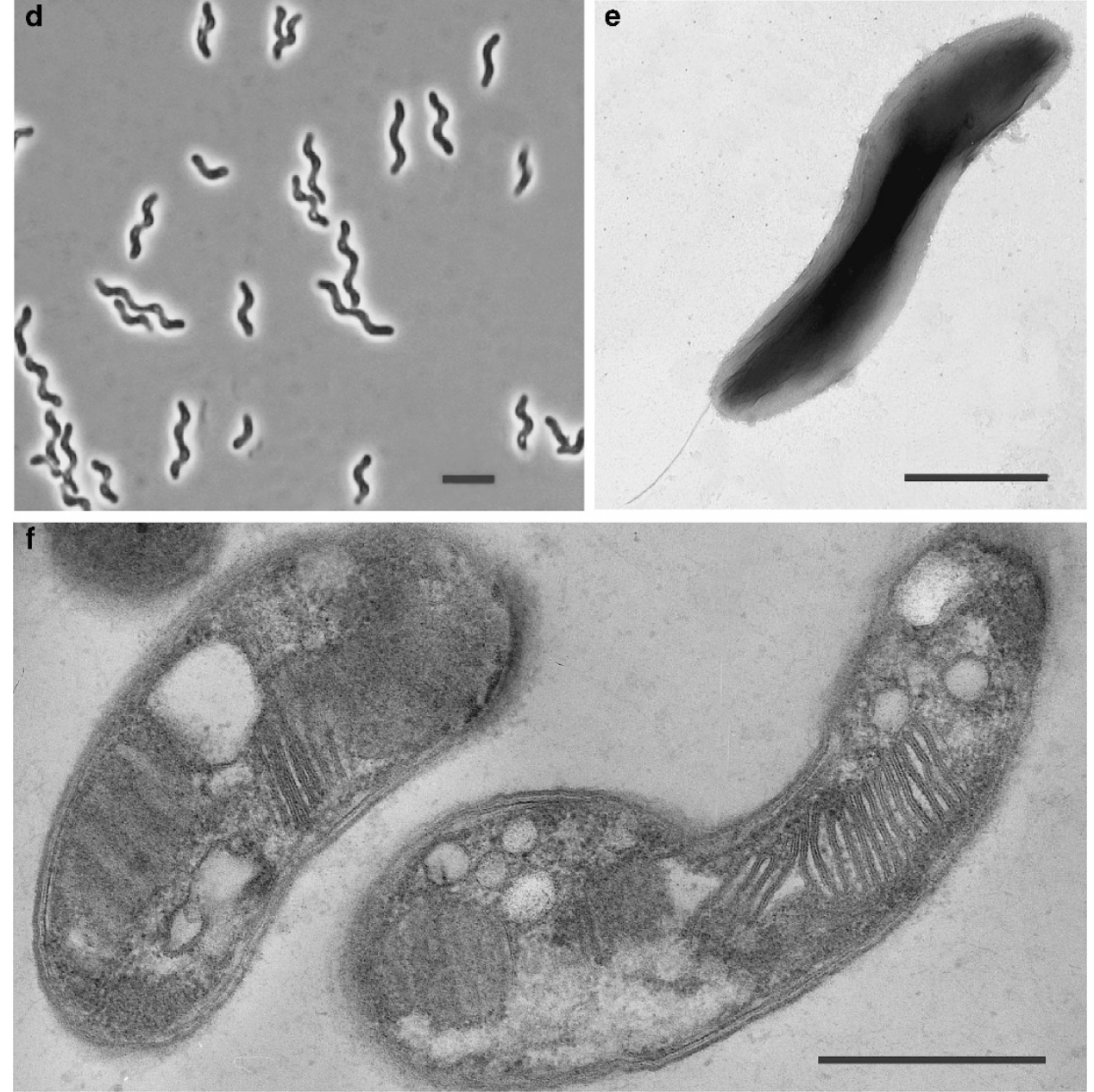

Figure $1 \quad(\mathbf{a}-\mathbf{c})$ Various cell morphotypes in a methanotrophic enrichment culture obtained from Sphagnum-derived peat: phase-contrast image (a), 4',6-diamidino-2-phenylindole (DAPI) staining (b), epifluorescent micrographs of whole-cell hybridization with Cy3-labeled probes M84+M705 (c); bar, $5 \mu \mathrm{m}$, applies to (a-c). (d) Phase-contrast micrograph of a culture of spiral-shaped bacteria obtained after multiple dilution series in mineral medium MG with methane as a growth substrate; bar, $2 \mu \mathrm{m}$. (e) Electron micrograph of a negatively stained spiral-shaped cell displaying a single polar flagellum; bar, $1 \mu \mathrm{m}$. (f) Ultrathin section of two spiral-shaped cells showing intracytoplasic membranes; bar, $0.5 \mu \mathrm{m}$.

least $1.5 \%$ of the strongest signal obtained for that probe with the validation set of reference strains/clones (Bodrossy et al., 2003; Stralis-Pavese et al., 2011).

\section{Nucleotide sequence accession numbers}

The 16S rRNA, pmoA and $c b b L$ gene sequences of 'Candidatus Methylospira mobilis' have been deposited in the GenBank, EMBL and DDBJ nucleotide sequence databases under accession numbers KU216206, KU216207 and KU568460, respectively.

\section{Results}

Enrichment cultures and purification attempts

Our study began with observations of spiral-shaped cells in a methanotrophic culture enriched from Sphagnum-derived peat sampled from the peat 
bog Shumnovo. Three major cell morphotypes were revealed in this enrichment culture: rods, large cocci and spiral-shaped cells (Figure 1a). All of them were targeted by the probe set M84+M705 (Figure 1c) with reported group specificity for methanotrophic Methylococcaceae (Eller et al., 2001). Large cocci and rodshaped bacteria were further isolated by plating on agar medium MG and identified as Methylovulum miyakonense and Methylomonas paludis, respectively (Danilova and Dedysh, 2014). Spiral-shaped cells, however, did not form colonies on solid media. They developed only in liquid mineral media under $\mathrm{CH}_{4}$ and displayed the preference for growth in static conditions. Inoculation of this culture into 25-ml test tubes containing $20 \mathrm{ml}$ of semisolid (0.1\% agar, w/v) medium MG and further incubation in jars with $30 \%$ $(\mathrm{v} / \mathrm{v})$ methane resulted in formation of growth rings at a depth of $0.2-0.4 \mathrm{~cm}$ below the medium surface. This observation suggested that spiral-shaped cells are sensitive to oxygen and grow better at a reduced oxygen tension. Our attempts to purify these microorganisms by serial dilutions in liquid and semiliquid media were only partially successful. After 2 years of repeated dilution series, we obtained a culture that was highly enriched with target spirilla (Figure 1d) and contained only a minor amount $(\sim 5 \%)$ of satellite bacteria. This culture grew optimally at temperatures between 14 and $25^{\circ} \mathrm{C}$ and in the $\mathrm{pH}$ range 6.0-6.5, although it was also capable of growth in more acidic ( $\mathrm{pH} 4.2-6.0$ ) and cold $\left(8-14^{\circ} \mathrm{C}\right)$ conditions. Spiralshaped cells in young cultures were highly motile and possessed one polar flagellum (Figure 1e). Thin sections of these cells displayed stacks of intracytoplasmic membranes, which are characteristic for methanotrophic Gammaproteobacteria (Figure 1f).

$16 S$ rRNA gene-based identification of spiral-shaped methanotrophs and satellite bacteria

In order to identify this unusual methanotroph, we analyzed a clone library ( $\sim 50$ clones) of 16S rRNA gene fragments amplified from DNA of a culture enriched with spiral-shaped cells. The majority of clones $(70 \%)$ were represented by one sequence type, which affiliated with the family Methylococcaceae and displayed 91-94\% similarity to $16 \mathrm{~S}$ rRNA gene sequences from Methylococcus and Methylocaldum species (Supplementary Figure S1). Based on this sequence, two 16S rRNA-targeted oligonucleotide probes, Spr206 and Spr845 (see Materials and methods), were developed for specific detection of the respective bacterium. Both probes hybridized to spiral-shaped cells (Supplementary Figure S2).

Two other 16S rRNA gene sequence types retrieved from the examined cell consortium belonged to Magnetospirullum- and Methylobacterium-like 'satellite' organisms. One group of these sequences displayed 93-94\% similarity to Magnetospirullum magneticum, a facultative anaerobic magnetotactic alphaproteobacterium. These microorganisms could easily be recognized in the consortium due to their specific cell morphology, that is, very thin and highly motile helical cells (Supplementary Figure S3). Another sequence type was equally divergent (1\% $16 \mathrm{~S}$ rRNA gene dissimilarity) from several described members of the genus Methylobacterium, M. aminovorans, $M$. poppuli and M. thiocyanatum. Cells representing this sequence type could also be observed by phase-contrast microscopy and appeared as non-motile short rods (Supplementary Figure S3). This cell morphology is typical for Methylobacterium species.

Identification based on pmo $A$ and $c b b L$ gene analyses We also analyzed a clone library of $p m o A$ gene fragments prepared from the same DNA extract of the culture enriched with target spirilla. Only one pmo $A$ sequence type was found. It belonged to the phylogenetic cluster containing PmoA sequences from gammaproteobacterial methanotrophs and formed a novel, genus-level lineage, which was only distantly related (81-86\% amino acid identity) to the PmoA cluster defined by the genera Methylococcus, Methylocaldum and Methylogaea (Figure 2a). Notably, this PmoA lineage included a number of sequences obtained in cultivation-independent studies from various freshwater environments, that is, peatlands, lake sediments, boreal forest and alpine fen soils (Pester et al., 2004; Jaatinen et al., 2005; Bussmann et al., 2006; Danilova and Dedysh, 2014; Cheema et al., 2015; Danilova et al., 2015). This PmoA lineage is also addressed as OSC (Organic Soil Cluster) cluster of uncultivated methanotrophs, which occur predominantly in peatlands and in some upland soils (Knief, 2015).

Given that the presence of RubisCO is one of the characteristic features of type X (Methylococcus-like) methanotrophs (Whittenbury and Dalton, 1981; Whittenbury, 1981; Baxter et al., 2002), we made an attempt to detect genes coding for this enzyme in spiral-shaped methanotrophs using the primer set developed by Alfreider et al. (2003). PCR product of the expected size (approximately $600 \mathrm{bp}$ ) was successfully obtained from DNA extract of the studied culture, cloned and analyzed. The retrieved CbbL sequence belonged to the clade of green-type form I RubisCO sequences represented by various autotrophic gamma- and alphaproteobacteria. The identity values between the $\mathrm{CbbL}$ sequence obtained in our study and the CbbL sequences from members of the genera Methylococcus and Methylocaldum were $89-90 \%$.

\section{pmoA-based microarray analyses}

The environmental distribution of methanotrophs representing this previously uncultivated group was evaluated in more detail using a pmoA-based microarray analysis (Bodrossy et al., 2003; StralisPavese et al., 2011). This lineage is targeted by 

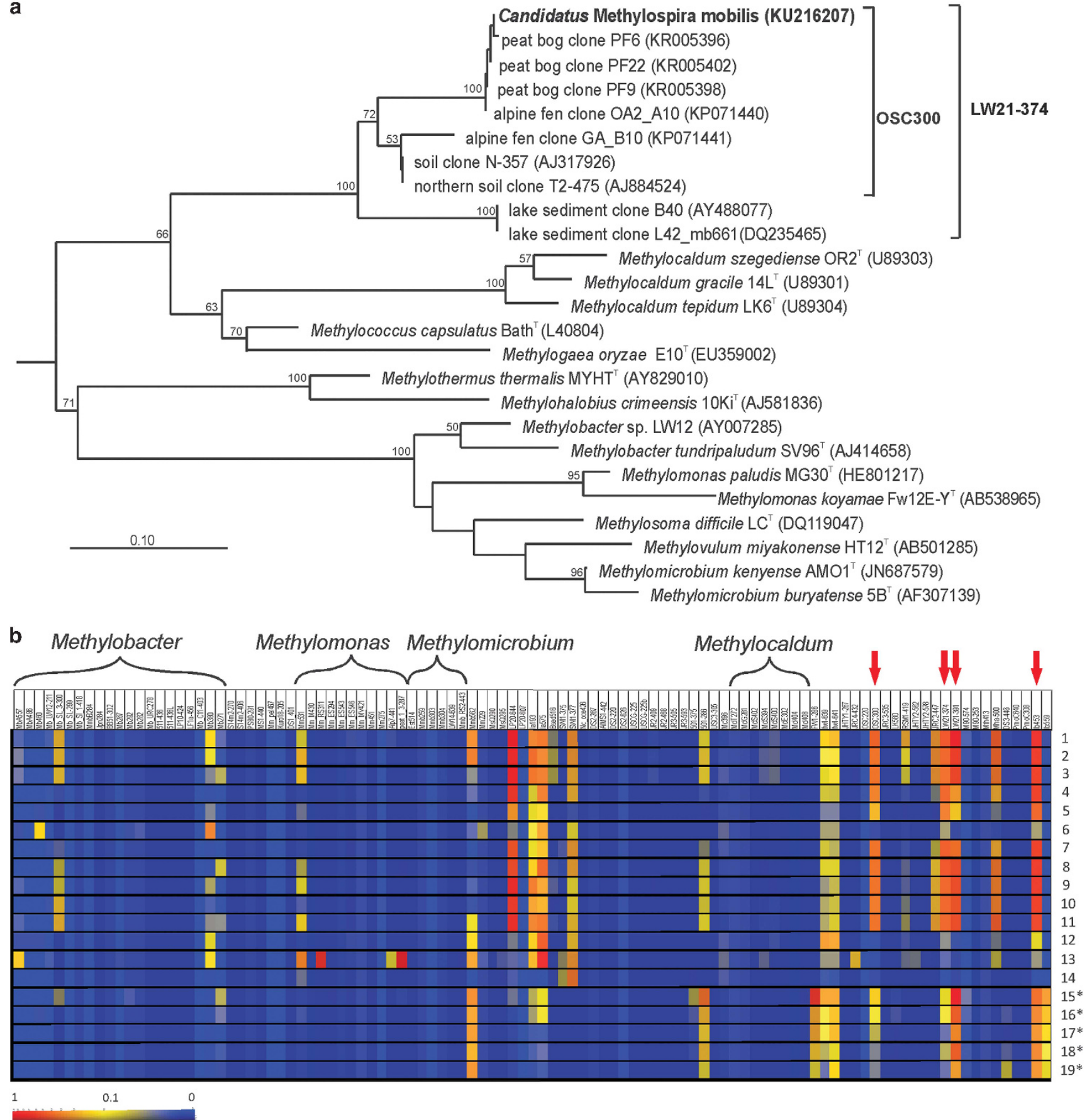

Figure 2 (a) Neighbor-joining tree constructed based on 144 deduced amino acid sites of partial pmo $A$ gene sequences, showing the position of spiral-shaped methanotroph relative to other representative members of the family Methylococcaceae and some environmental PmoA sequences obtained in cultivation-independent studies. Six PmoA sequences from alphaproteobacterial methanotrophs were used as an outgroup. GenBank accession numbers of representative clones are given in parentheses. Bootstrap values (percentages of 1000 data resamplings) $>50 \%$ are shown. The scale bar represents 0.1 changes per amino acid position. The brackets indicate the scope of the pmoA-specific probes OSC300 and LW21-374. (b) Methanotroph diversity analysis using a pmoA microarray. Relative signal intensities of the probes are indicated by the different colors as shown on the color bar, a value of 1 corresponding to the maximum achievable signal for an individual probe. The colors on the heatmap do not quantitatively reflect the relative abundance distribution of the total methanotroph community and should only be considered a strong indication whether or not a given methanotroph makes up a minor or major proportion of the total methanotroph community. Only the probes corresponding to type I methanotrophs are shown. Red arrows point to the probes OSC300, LW21-374, LW21-391 and Ib453 that target the pmoA lineage described in this study. The pmoA clone AJ317926 (see the tree in panel a) was used to establish the maximum signal strengths for the probes OSC300 and LW21-374. Samples 1-12 are from Northern Russia and samples 13-14 are from Norway. Details regarding the nature of these samples and location of the sampling sites are given in Table 1. The results for the samples 15-19 are cited from Siljanen et al. (2011) and correspond to the littoral wetland of a boreal lake in Finland. The whole range of methanotroph diversity and diversity of type II methanotrophs in these samples are displayed in Supplementary Figure S4. 

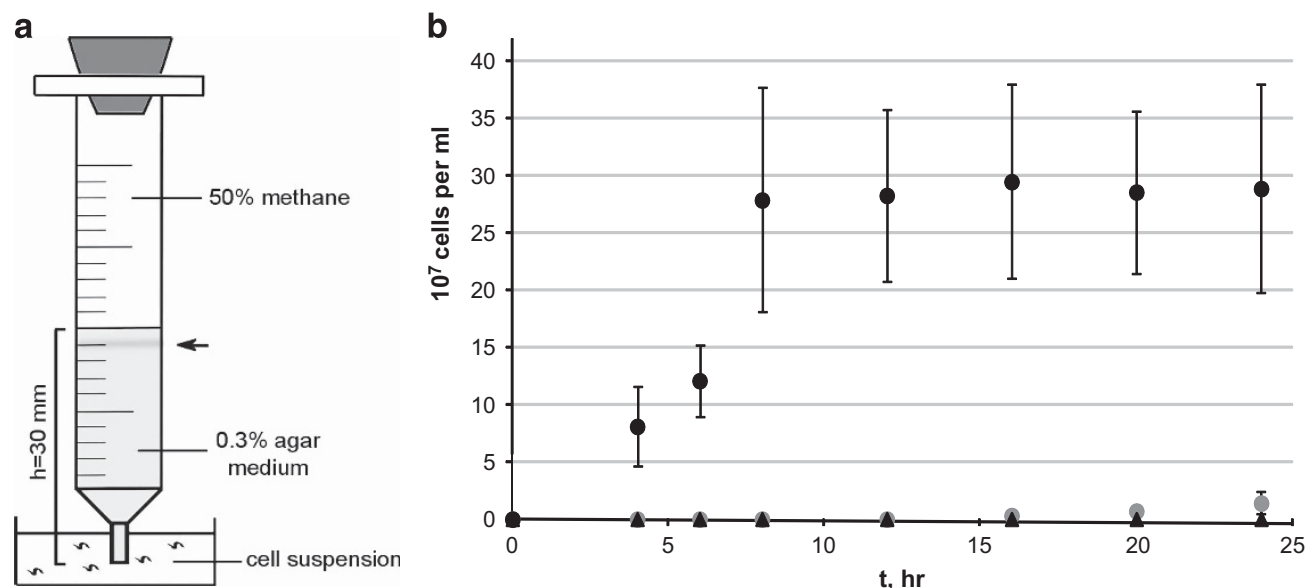

Figure 3 (a) The experimental setup used to determine $\mathrm{CH}_{4}$-tactic response of spiral-shaped methanotrophs. Black arrow points to the subsurface faint band of cells, which is formed after $24 \mathrm{~h}$ of incubation with $50 \%$ (v/v) methane in the headspace of syringes. (b) Dynamics of spiral-shaped methanotrophs accumulation in a subsurface agar layer during incubation with (black circles) and without (gray circles) methane. Results of the similar experiment with Methylomonas methanica S1 are shown by triangles. The data are means of triplicates \pm s.e.m.

probes OSC300, LW21-374 and LW21-391, as well as the broad specificity probe Ib453 (see Figure 2a and Supplementary file with probe specificity). Microarray data indicated that members of this lineage were present at levels significantly above background in a diverse range of samples collected from wetlands and freshwater sediments in Northern Russia (samples 1-5 and 7-11 in Figure 2b and Table 1). Weak probe-conferred signals were obtained from peat material collected at the isolation site, that is, the bog Shumnovo (sample 12), as well as from the sediment of a thermocarst pond in Norway (sample 13). Among all earlier examined environments, notable presence of methanotrophs from this $p m o A$ lineage was detected in the littoral wetland of a boreal lake in Finland (Siljanen et al., 2011, samples 15-19 in Figure 2b). A group of phylogenetically related methanotrophs with $p m o A$ sequences targeted by the probes LW21-374 and LW21-391, but not by the probe OSC300, was detected in several Finnish peatlands (Putkinen et al., 2012; 2014). Together, the results suggest that representatives of this $p m o A$ clade are widely distributed in northern freshwater environments.

\section{$\mathrm{CH}_{4}$ - and $\mathrm{O}_{2}$-taxis experiments}

To examine the advantage given by the helical cell shape, we determined $\mathrm{CH}_{4}$-tactic responses of these methanotrophs using a syringe migration assay (Figure 3a). The cells were offered a possibility of migrating into the syringes, which were partially filled with a semisolid agar $(0.3 \%, \mathrm{w} / \mathrm{v})$ medium and contained $50 \%$ methane in the headspace. Single cells arriving in the subsurface medium layer $(2 \mathrm{~mm}$ depth) of these syringes were observed already after $1 \mathrm{~h}$ of incubation, although the first results of migration process could reliably be documented after $4 \mathrm{~h}$ of incubation (Figure $3 \mathrm{~b}$ ). After $24 \mathrm{~h}$ of incubation, a subsurface faint band of accumulating cells was seen with the naked eye. Some cell migration was also observed in control incubations without methane, but its intensity was far lower than that in the presence of $\mathrm{CH}_{4}$ (Figure $3 \mathrm{~b}$ ) and no band formation was observed in this case. Presumably, this weak migration of cells in control experiments was due to their movement towards the optimal $\mathrm{O}_{2}$ concentration. We also attempted to examine the migration capability of spiral-shaped methanotrophs in a heterogeneous, 'sediment-like' substrate. For this, we added glass beads (diameter $1 \mathrm{~mm}$ ) to a semisolid agar $(0.3 \%, \mathrm{w} / \mathrm{v})$ medium. The same kind of migration was observed in this case as well, except that the cell velocity was even higher than in a homogeneous semisolid medium. The moving velocities in a semisolid medium and a 'sedimentlike' substrate were $0.5-2.0$ and $3.0-6.0 \mu \mathrm{m} \mathrm{s}^{-1}$, respectively.

Similar tests were performed with the non-spiral, motile methanotroph Methylomonas methanica S1. Although these bacteria were also capable of a limited migration over relatively thin $(1-10 \mathrm{~mm}$ thick) layers of a semisolid medium, they failed to pass through 3-cm-thick gel or 'sediment-like' layers tested in our experiments (Figure 3).

Given the possibility of purifying the spiral-shaped methanotroph using this taxis assay, we attempted to resume our isolation work. Several months of repeated $\mathrm{CH}_{4}$-forced migration experiments, however, did not eliminate 'satellite' bacteria. Owing to a similar helical cell morphology and the preference for micro-oxic conditions, Magnetospirillum-like 'satellites' also migrated into the syringes. Although Methylobacterium-like cells were not capable of migrating themselves, they tended to move in a 'horse-riding' manner being tightly attached to cells of methanotrophs (Supplementary Figure S3C). Since the spiral-shaped methanotroph described here has not been isolated in a pure culture, we propose a Candidatus status for this bacterium. 
Description of 'Candidatus Methylospira mobilis' (Me.thy.lo.spi'ra. N.L. n. methylum the methyl group; Gr. n. spira the spiral; N.L. fem. n. Methylospira methyl-using spiral; mo'bi.lis. L. fem. adj. mobilis movable, motile). Gram-negative, spiral-shaped cells containing stacks of intracytoplasmic membranes. Divide by binary fission. Highly motile by means of a polar flagellum. Obligately microaerophilic. Utilize methane as the only carbon and energy source. Possess particulate MMO. Genes encoding form I RubisCO are present. Optimal growth at 14-25 ${ }^{\circ} \mathrm{C}$ and $\mathrm{pH}$ 6.0-6.5. Inhabit northern freshwater habitats including peatlands, organic soils and sediments. Can be detected by $16 \mathrm{~S}$ rRNA-targeted probes Spr206 and Spr845. Member of the family Methylococcaceae.

\section{Discussion}

Although cultured methanotrophic Gammaproteobacteria are traditionally defined as strictly aerobic microorganisms, their activity under micro-oxic conditions is well recognized. The latter is of special importance for dinitrogen-fixing type $\mathrm{I}$ and $\mathrm{X}$ methanotrophs since $\mathrm{N}_{2}$ fixation in these bacteria is more sensitive to $\mathrm{O}_{2}$ than in type II methanotrophs (Murrell and Dalton, 1983; Dedysh et al., 2004). In nitrogen-sufficient media, however, most described methanotrophs display best growth under fully oxic conditions. Two known exceptions are Methylosoma difficile and Methyloglobulus morosus (Rahalkar et al., 2007; Deutzmann et al., 2014), which were isolated from lake sediments and show optimal growth at low-oxygen tensions. These microaerophilic methanotrophs, however, could grow and form colonies on solid media though could not be maintained on these media by repeated transfers. By contrast, we failed to obtain any growth of the spiral-shaped methanotroph on solid media. This bacterium represents a distinctive example of an obligate microaerophilic methanotroph. A helical cell shape is known to be related to the ability of bacteria to move through a relatively viscous environment (Zinder, Dworkin, 2013). Moreover, the swimming speed increases with viscosity, which is caused by a loose, quasi-rigid network formed by polymer molecules (Berg and Turner, 1979). As shown by mathematical modeling, a long, thin, helical shape is suitable for fast swimming in viscous conditions containing polymer molecules because of the improved propulsion efficiency (Magariyama and Kudo, 2002). Organic sediments, layers of partially decomposed plant debris in peatlands and microbial biofilms that are formed at oxic-anoxic interfaces in freshwater ecosystems are good examples of heterogeneous and potentially viscous habitats. We conclude that the helical morphology may be an important part of the adaptive strategy of Candidatus Methylospira mobilis, enabling it to occupy low oxygen/high methane zones within habitats that are predicted to be physically difficult to access for microaerophilic methanotrophs with conventional cell morphology. In Sphagnum-dominated wetlands, this moving ability could also be helpful in colonizing hyaline cells of Sphagnum mosses. Methanotrophs phylogenetically related to Candidatus Methylospira mobilis and detected by the probes LW21-374 and LW21-391 were apparently able to immigrate through water dispersal from Sphagnum cuspidatum to inactive Sphagnum rubellum mosses (Putkinen et al., 2012).

Despite 3 years of continuous purification work, the spiral-shaped microaerophilic methanotroph could not be obtained in an axenic culture. The recent discovery of glycolysis-based methane assimilation and production of acetate and hydrogen by methanotrophs under oxygen limitation (Kalyuzhnaya et al., 2013) could explain the occurrence of Magnetospirullum-like 'satellites', which use acetate as the electron donor for heterotrophic growth (Schleifer et al., 1991; Thrash et al., 2010). Some members of this genus, like Magnetospirullum bellicus, could also grow chemolithotrophically with hydrogen serving as the electron donor (Thrash et al., 2010). Close metabolic association of methanotrophs with Methylobacterium species is well recognized (Kelly et al., 2014). Although various procedures have been described to purify a methanotroph from non-methanotrophic 'satellites' (Dedysh and Dunfield, 2014), none of them appears to be efficient for obligate microaerophilic methanotrophs.

Recent research demonstrates that microaerobic methanotrophy is of significant ecological importance (Blees et al., 2014; Bar-Or et al., 2015; Chistoserdova, 2015; Hernandez et al., 2015). Most of these studies refer to lake sediments. Apparently, microaerobic methanotrophy is of high relevance for wetlands as well but did not receive significant research attention due to methodological problems of measuring $\mathrm{O}_{2}$ gradients in these ecosystems. As shown in our study, spiral-shaped microaerophilic methanotrophs are widely distributed in various northern water-saturated environments, such as lake and river sediments as well as peatlands. One particular aspect of their environmental distribution pattern deserves additional attention. As mentioned above, these bacteria are type Ib (formerly type X) methanotrophs. The first described members of this group, that is, representatives of the genera Methylococcus and Methylocaldum, are moderately thermophilic/thermotolerant bacteria. The whole group, therefore, is often referred to as preferring thermal habitats. This view, however, appears to be incorrect. Analysis of a large data set of pmoA sequences from type Ib methanotrophs retrieved from various environments indicated that the majority of these sequences originated from water-saturated, potentially micro-oxic habitats and only a minor part of them were retrieved from thermal environments (Supplementary Figure S5). The situation that most described thermophiles belong to this group may be due to the fact that most isolation 
efforts have so far been focused on hot springs. Phenotypically, the spiral-shaped methanotroph described in our study is distinct from Methylococcus and Methylocaldum species. Other, as-yetuncultivated type Ib methanotrophs from nonthermal micro-oxic environments may also possess a number of unique features and specific adaptations, which determine their environmental distribution pattern. Apparently, more efforts are needed to adjust the techniques for isolation of microaerophilic methanotrophs and to explore the diversity and biology of these environmentally relevant microorganisms.

\section{Conflict of Interest}

The authors declare no conflict of interest.

\section{Acknowledgements}

This research was supported by the collaborative project between the Russian Fund of Basic Research (project No14-04-93082) and The Research Council of Norway (233645/H30), and the Program 'Molecular and Cell Biology' of Russian Academy of Sciences. LB acknowledges the financial support of the CSIRO OCE Science Leader scheme. We thank AG Hestnes for assistance in preparing DNA samples for microarray analysis and VN Khmelenina for providing the culture of Methylomonas methanica S1.

\section{References}

Alfreider A, Vogt C, Hoffmann D, Babel W. (2003). Diversity of ribulose-1,5-bisphosphate carboxylase/ oxygenase large-subunit genes from groundwater and aquifer microorganisms. Microb Ecol 45: 317-328.

Bar-Or I, Ben-Dov E, Kushmaro A, Eckert W, Sivan O. (2015). Methane-related changes in prokaryotes along geochemical profiles in sediments of Lake Kinneret (Israel). Biogeosciences 12: 2847-2860.

Baxter NJ, Hirt RP, Bodorossy L, Kovacs KL, Embley TM, Prosser JI et al. (2002). The ribulose-1,5-bisphosphate carboxylase/oxygenase gene cluster of Methylococcus capsulatus (Bath). Arch Microbiol 177: 279-289.

Berg HC, Turner L. (1979). Movement of microorganisms in viscous environments. Nature 278: 349-351.

Blees J, Niemann H, Wenk CB, Zopfi J, Schubert CJ, Kirf MK et al. (2014). Micro-aerobic bacterial methane oxidation in the chemocline and anoxic water column of deep south-Alpine Lake Lugano (Switzerland). Limnol Oceanogr 59: 311-324.

Bodrossy L, Holmes EM, Holmes AJ, Kovac KL, Murrell JC. (1997). Analysis of $16 \mathrm{~S}$ rRNA and methane monooxygenase gene sequences reveals a novel group of thermotolerant and thermophilic methanotrophs, Methylocaldum gen. nov. Arch Microbiol 168: 493-503.

Bodrossy L, Stralis-Pavese N, Murrell JC, Radajewski S, Weilharter A, Sessitsch A. (2003). Development and validation of a diagnostic microbial microarray for methanotrophs. Environ Microbiol 5: 566-582.

Bowman J. (2006). The methanotrophs-the families Methylococcaceae and Methylocystaceae. In: Dworkin M, Falkow S, Rosenberg E, Schleifer KH, Stackebrandt E (eds), The Prokaryotes: A Handbook on the Biology of Bacteria, 3rd edn, vol. 5. Springer: New York, pp 266-289.

Bussmann I, Rahalkar M, Schink B. (2006). Cultivation of methanotrophic bacteria in opposing gradients of methane and oxygen. FEMS Microbiol Ecol 56: 331-344.

Cheema S, Zeyer J, Henneberger R. (2015). Methanotrophic and methanogenic communities in Swiss Alpine fens dominated by Carex rostrata and Eriophorum angustifolium. Appl Environ Microbiol 81: 5832-5844.

Chistoserdova L. (2015). Methylotrophs in natural habitats: current insights through metagenomics. Appl Microbiol Biotechnol 99: 5763-5779.

Chistoserdova L, Lidstrom ME. (2013). Aerobic methylotrophic prokaryotes. In: Rosenberg E, DeLong EF, Lory S, Stackebrandt E, Thompson F (eds), The Prokaryotes-Prokaryotic Physiology and Biochemistry. Springer-Verlag: Berlin Heidelberg, pp 267-285.

Danilova OV, Dedysh SN. (2014). Abundance and diversity of methanotrophic Gammaproteobacteria in northern wetlands. Microbiology (transl. from Mikrobiologija) 83: $67-76$.

Danilova OV, Belova SE, Kulichevskaya IS, Dedysh SN. (2015). Decline of activity and shifts in the methanotrophic community structure of an ombrotrophic peat bog after wildfire. Microbiology (transl. from Mikrobiologija) 84: 624-629.

Dedysh SN, Derakshani M, Liesack W. (2001). Detection and enumeration of methanotrophs in acidic Sphagnum peat by 16S rRNA fluorescence in situ hybridization, including the use of newly developed oligonucleotide probes for Methylocella palustris. Appl Environ Microbiol 67: 4850-4857.

Dedysh SN, Ricke P, Liesack W. (2004). NifH and NifD phylogenies: an evolutionary basis for understanding nitrogen fixation capabilities of methanotrophic bacteria. Microbiology 150: 1301-1313.

Dedysh SN, Dunfield PF. (2014). Cultivation of methanotrophic bacteria. In: McGenity TJ, Timmis KN, Nogales B (eds), Hydrocarbon and Lipid Microbiology Protocols. Springer Protocols Handbooks. Springer-Verlag: Berlin Heidelberg.

Deutzmann JS, Hoppert M, Schink B. (2014). Characterization and phylogeny of a novel methanotroph, Methyloglobulus morosus gen. nov., spec. nov. Syst Appl Microbiol 37: 165-169.

Dumont MG. (2014). Primers: functional marker genes for methylotrophs and methanotrophs. In: McGenity TJ et al. (eds), Hydrocarbon and Lipid Microbiology Protocols, Springer Protocols Handbooks. SpringerVerlag: Berlin Heidelberg.

Eller G, Stubner S, Frenzel P. (2001). Group specific 16S rRNA targeted probes for the detection of type I and type II methanotrophs by fluorescence in situ hybridization. FEMS Microbiol Lett 198: 91-97.

Geymonat E, Ferrando L, Tarlera SE. (2010). Methylogaea oryzae gen. nov., sp. nov., a novel mesophilic methanotroph from a rice paddy field in Uruguay. Int J Syst Evol Microbiol 61: 2568-2572.

Hernandez ME, Beck DAC, Lidstrom ME, Chistoserdova L. (2015). Oxygen availability is a major factor in determining the composition of microbial communities involved in methane oxidation. Peer J 3: e801.

Hoefman S, Van der Ha D, Iguchi H, Yurimoto H, Sakai Y, Boon N et al. (2014). Methyloparacoccus murrellii gen. nov., sp. nov., a methanotroph isolated from pond water. Int J Syst Evol Microbiol 64: 2100-2107. 
Holmes A J, Costello A, Lidstrom ME, Murrell JC. (1995). Evidence that particulate methane monooxygenase and ammonium monooxygenase may be evolutionarily related. FEMS Microbiol Lett 132: 203-208.

Jaatinen K, Tuittila ES, Laine J, Yrjala K, Fritze H. (2005). Methane-oxidizing bacteria in a Finnish raised mire complex: effects of site fertility and drainage. Microb Ecol 50: 429-439.

Kalyuzhnaya MG, Yang S, Rozova ON, Smalley NE, Clubb J, Lamb A et al. (2013). Highly efficient methane biocatalysis revealed in a methanotrophic bacterium. Nat Commun 4: 2785.

Kelly DP, McDonald IR, Wood AP. (2014). The family Methylobacteriaceae. In: Rosenberg E et al. (eds), The Prokaryotes-Alphaproteobacteria and Betaproteobacteria. Springer-Verlag: Berlin Heidelberg, pp 331-340.

Knief C. (2015). Diversity and habitat preferences of cultivated and uncultivated aerobic methanotrophic bacteria evaluated based on pmoA as molecular marker. Front Microbiol 6: 1346.

Ludwig W, Strunk O, Westram R, Richter L, Meier H, Yadhukumar et al. (2004). ARB: a software environment for sequence data. Nucl Acids Res 32: 1363-1371.

Magariyama Y, Kudo S. (2002). A mathematical explanation of an increase in bacterial swimming speed with viscosity in linear-polymer solutions. Biophys $J$ 83: 733-739.

McDonald IR, Bodrossy L, Chen Y, Murrell JC. (2008). Molecular ecology techniques for the study of aerobic methanotrophs. Appl Environ Microbiol 74: 1305-1315.

Murrell JC, Dalton H. (1983). Nitrogen fixation in obligate methanotrophs. J Gen Microbiol 129: 3481-3486.

Nazaries L, Murrell JC, Millard P, Baggs L, Singh BK. (2013). Methane, microbes and models: fundamental understanding of the soil methane cycle for future predictions. Environ Microbiol 15: 2395-2417.

Op den Camp HJM, Islam T, Stott MB, Harhangi HR, Hynes A, Schouten $S$ et al. (2009). Environmental, genomic and taxonomic perspectives on methanotrophic verrucomicrobia. Environ Microbiol Rep 1: 293-306.

Pester M, Friedrich MW, Schink B, Brune A. (2004) pmoA-based analysis of methanotrophs in a littoral lake sediment reveals a diverse and stable community in a dynamic environment. Appl Environ Microbiol 70: 3138-3142.

Putkinen A, Larmola T, Tuomivirta T, Siljanen HMP, Bodrossy L, Tuittila E-S, Fritze H. (2012). Water dispersal of methanotrophic bacteria maintains functional methane oxidation in Sphagnum mosses. Front Microbiol 3: 15.

Putkinen A, Larmola T, Tuomivirta T, Siljanen HMP, Bodrossy L, Tuittila E-S, Fritze H. (2014). Peatland succession induces a shift in the community composition of Sphagnum-associated active methanotrophs. FEMS Microbiol Ecol 88: 596-611.

Rahalkar M, Bussmann I, Schink B. (2007). Methylosoma difficile gen. nov., sp. nov., a novel methanotroph enriched by gradient cultivation from littoral sediment of Lake Constance. Int J Syst Evol Microbiol 57: 1073-1080.

Reynolds ES. (1963). The use of lead citrate at high pH as an electron-opaque stain in electron microscopy. J Cell Biol 17: 208-213.
Semrau JD, DiSpirito AA, Yoon S. (2010). Methanotrophs and copper. FEMS Microbiol Rev 34: 496-531.

Sharp CE, Smirnova AV, Graham JM, Stott MB, Khadka R, Moore TR et al. (2014). Distribution and diversity of Verrucomicrobia methanotrophs in geothermal and acidic environments. Environ Microbiol 16: 1867-1878.

Schleifer K-H, Schuler D, Spring S, Weizenegger M, Amann R, Ludwig W, Kohler M. (1991). The genus Magnetospirillum gen. nov. Description of Magnetospirillum gryphiswaldense sp. nov. and transfer of Aquaspirillum magnetotacticum to Magnetospirillum magnetotacticum comb. nov. Syst Appl Microbiol 14: 379-385.

Siljanen HMP, Saari A, Krause S, Lensu A, Abell GCJ, Bodrossy L et al. (2011). Hydrology is reflected in the functioning and community composition of methanotrophs in the littoral zone of a boreal lake. FEMS Microbiol Ecol 75: 430-445.

Stoecker K, Bendinger B, Schöning B, Nielsen PH, Nielsen JL, Baranyi C et al. (2006). Cohn's Crenothrix is a filamentous methane oxidizer with an unusual methane monooxygenase. Proc Natl Acad Sci USA 103: 2363-2367.

Stralis-Pavese N, Abell GCJ, Sessitsch A, Bodrossy L. (2011). Analysis of methanotroph community composition using a pmoA-based microbial diagnostic microarray. Nat Protocols 6: 609-624.

Takeuchi M, Kamagata Y, Oshima K, Hanada S, Tamaki H, Marumo K et al. (2014). Methylocaldum marinum sp. nov., a thermotolerant, methane-oxidizing bacterium isolated from marine sediments and emended description of the genus Methylocaldum. Int J Syst Evol Microbiol 64: 3240-3246.

Thrash JC, Ahmadi S, Torok T, Coates JD. (2010). Magnetospirillum bellicus sp. nov., a novel dissimilatory perchlorate-reducing alphaproteobacterium isolated from a bioelectrical reactor. Appl Environ Microbiol 76: 4730-4737.

Tout J, Jeffries TC, Petrou K, Tyson GW, Webster NS, Garren $\mathrm{M}$ et al. (2015). Chemotaxis by natural populations of coral reef bacteria. ISME J 9: 1764-1777.

Trotsenko YA, Murrell JC. (2008). Metabolic aspects of aerobic obligate methanotrophy. Adv Microbiol 63: 183229

Weisburg WG, Barns SM, Pelletier DA, Lane DJ. (1991). $16 \mathrm{~S}$ ribosomal DNA amplification for phylogenetic study. J Bacteriol 173: 697-703.

Whittenbury R. (1981). The interrelationship of autotrophy and methylotrophy as seen in Methylococcus capsulatus (Bath). In: Dalton H (ed), Microbial Growth on C1 Compounds. Heyden: London, pp 181-190.

Whittenbury R, Dalton H. (1981). The methylotrophic bacteria. In: Starr MP, Stolph H, Trüper HG, Balows A, Schlegel HG (eds), The Prokaryotes. Springer-Verlag KG: Berlin, pp 894-902.

Wolin EA, Wolin MG, Wolfe RS. (1963). Formation of methane by bacterial extracts. $J$ Biol Chem 238: 2882-2886.

Zinder SH, Dworkin M. (2013). Morphological and physiological diversity. In: Rosenberg E, DeLong EF, Lory S, Stackebrandt E, Thompson F (eds), The Prokaryotes-Prokaryotic Biology and Symbiotic Associations. Springer-Verlag: Berlin, Heidelberg.

Supplementary Information accompanies this paper on The ISME Journal website (http://www.nature.com/ismej) 